\title{
"Oil price movements, exchange rate and Nigerian manufacturing sector growth: a short-run analysis"
}

\begin{tabular}{|c|c|}
\hline AUTHORS & $\begin{array}{l}\text { Adeleke Omolade (D https://orcid.org/0000-0003-3306-3879 } \\
\text { Harold Ngalawa iD http://orcid.org/0000-0002-1946-3983 }\end{array}$ \\
\hline ARTICLE INFO & $\begin{array}{l}\text { Adeleke Omolade and Harold Ngalawa (2018). Oil price movements, exchange } \\
\text { rate and Nigerian manufacturing sector growth: a short-run analysis. Investment } \\
\text { Management and Financial Innovations, 15(3), 329-342. doi: } \\
\text { 10.21511/imfi.15(3).2018.27 }\end{array}$ \\
\hline DOI & http://dx.doi.org/10.21511/imfi.15(3).2018.27 \\
\hline RELEASED ON & Wednesday, 26 September 2018 \\
\hline RECEIVED ON & Tuesday, 30 January 2018 \\
\hline ACCEPTED ON & Thursday, 30 August 2018 \\
\hline LICENSE & $\begin{array}{l}(c)) \text { EY-NC } \\
\text { This work is licensed under a Creative Commons Attribution-NonCommercial } 4.0 \\
\text { International License }\end{array}$ \\
\hline JOURNAL & "Investment Management and Financial Innovations" \\
\hline ISSN PRINT & $1810-4967$ \\
\hline ISSN ONLINE & $1812-9358$ \\
\hline PUBLISHER & LLC "Consulting Publishing Company "Business Perspectives" \\
\hline FOUNDER & LLC "Consulting Publishing Company "Business Perspectives" \\
\hline
\end{tabular}

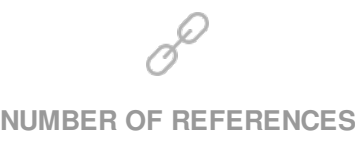

42

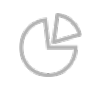

NUMBER OF FIGURES

10

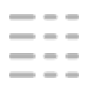

NUMBER OF TABLES

4

(C) The author(s) 2022. This publication is an open access article. 


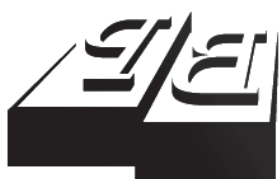

BUSINESS PERSPECTIVES

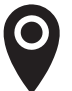

LLC "CPC "Business Perspectives" Hryhorii Skovoroda lane, 10, Sumy, 40022, Ukraine

www.businessperspectives.org

Received on: $30^{\text {th }}$ of January, 2018 Accepted on: $30^{\text {th }}$ of August, 2018

(C) Adeleke Omolade, Harold Ngalawa, 2018

Adeleke Omolade, Ph.D., School of Accounting, Economics and Finance, College of Law and Management Studies, University of KwaZulu-Natal, South Africa.

Harold Ngalawa, Ph.D., School of Accounting, Economics and Finance, College of Law and Management Studies, University of KwaZulu-Natal, South Africa.

\section{OIL PRICE MOVEMENTS,} EXCHANGE RATE AND NIGERIAN MANUFACTURING SECTOR GROWTH: A SHORT-RUN ANALYSIS

\begin{abstract}
The paper conducts a short-run analysis of the implications of oil price movements and exchange rate relationship for the Nigerian manufacturing sector growth between January 2008 and September 2017. Monthly data are extracted on variables such as oil price, exchange rate, inflation rate, interest (lending) rate, money supply and the manufacturing sector growth rate. Oil price movements are viewed in terms of both volatility and change. While EGARCH is used to estimate oil price volatility, oil price change is measured using Hamilton index for both oil price sharp drop and jump. The SVAR results indicate that exchange rate and inflation rate are more responsive to sharp drop in oil price. The two variables also have the highest impact on the manufacturing sector growth. Findings further indicate that Nigerian manufacturing sector is more affected at the cost side than the output side. This underscores the importance of tackling the inflation pressure in Nigeria from the structural perspective as against the monetary perspective.
\end{abstract}

Keywords

JEL Classification growth oil price change, exchange rate, manufacturing sector

\section{INTRODUCTION}

The trends of events in Nigeria in the recent times have brought about more quest for economic diversification, in which the manufacturing sector has been one of the major sectors in the economy primed to champion the course. Nevertheless, the vulnerability of the macroeconomic variables in the country to oil price movements has taken its toll on the growth of the manufacturing sector since 1979 when the country recorded the first oil boom. During this period, the price of oil rose astronomically from 56 USDpb to as high as 100 USDpb. This prompted the government to shift attention from other sectors to the oil sector leading to the problem of Dutch Disease (Resource Curse) (CBN, 2015). However, in the early 80s, there was oil glut and the economy was plunged into its first economic recession, which affected all sectors of the economy including the manufacturing sector. However, the manufacturing sector since then has been experiencing unbalance and unsustainable output growth thus hindering the sector from playing its role in the diversification process to rescue the economy from its feeble economic status (Adeniyi, 2011).

This is an Open Access article, distributed under the terms of the Creative Commons Attribution-NonCommercial 4.0 International license, which permits re-use, distribution, and reproduction, provided the materials aren't used for commercial purposes and the original work is properly cited.
Moreover, within the last one decade, the Nigerian economy again has been experiencing another round of oil price shock, which finally plunged the economy into another economic recession in the third quarter of 2016. The sharp drop in oil price in the middle of 2014 from 
114 USDpb to as low as 31 USDpb in the first quarter of 2016 brought serious macroeconomic implications for the economy, with the naira crashing drastically to a decade low of N 385 to 1 USD in the middle of 2016 (CBN, 2017). During this period, the manufacturing Purchasing Manager Index (PMI), which measures the health of the manufacturing sector, fell from 59.7\% in 2014 to all time low of $41.2 \%$ in 2016 second quarter. The CPI inflation rate also rose from a single digit of $7.9 \%$ in the last quarter of 2014 to $16.4 \%$ in the second quarter of 2016. Within the first and second quarter of the same year, Nigeria recorded the second successive negative growth rate and the economy was pronounced recessed in the third quarter of 2016. All these chains of reactions to oil price movements open more discussions on the nature of its influence on the Nigerian economy.

However, to combat the economic hardship, the CBN stepped in with some monetary policy measures aimed at improving investment and controlling the rising inflation trend. Firstly, to boost investment, the CBN devalued the naira in the second quarter of 2016 and secondly, to curb the rising trend of inflation, the CBN increased the monetary policy rate from $12 \%$ in the last quarter of 2015 to $14 \%$ in the second quarter of 2016. Both devaluation and contractionary monetary policy, which jacked the lending rate from $16.96 \%$ in the last quarter of 2015 to $17.54 \%$ in the second quarter of 2016, compounded the woes of the manufacturing sector. This made the sector to record second successive negative growth rate in the third quarter of 2016 (IMF, 2016).

From the empirical literature, there has been lack of consensus on the influence of oil price movements on exchange rate and output. Therefore, it appears that the right exchange rate policy to adopt by oil exporting countries whenever there are oil price shocks remains inconclusive. The study of Iwayemi and Fowowe (2010), and Adeniyi et al. (2011) concluded that oil exporting countries are faced with output decline during negative oil price shocks, especially when the fall is sharp. According to them, monetary authorities are expected to devalue the currency to attract foreign investors and discourage importation, because this will improve domestic output. However, Spatafora and Stavrev (2003) and Oomes and Kalacheva (2007) opined that this conclusion might be counterproductive for many of the oil exporting countries that depend solely on importation of basic items such as capital goods and raw materials for local manufacturers. According to them, this action will further plunge the domestic output, hence, devaluation might not be the best line of action. Another argument on the appropriate exchange rate policy during oil price shocks was brought forward in the study of Kalamova (2007) where it was concluded that countries need to always maintain a fixed exchange rate regime during oil price decline by using their external reserves as a buffer. This, according to the study, will limit the adverse effect on the manufacturing output and it will ensure economic stability. However, the study of Nikbakht (2010) showed that using external reserves as a buffer during this period might be short-lived and unsustainable, especially if the decline in oil price is prolonged. Nikbakht (2010) further suggested leaving the exchange rate for the market to determine as it will pave way for a long-run economic stability and thus make the manufacturing sector more competitive.

The lines of arguments highlighted above are clear indications that the relationship between oil price movements, exchange rate and manufacturing output in an oil producing country like Nigeria requires further empirical investigations. This is the major objective of this study and the rest of this paper discusses the methodology, results, conclusions and recommendations.

\section{METHODOLOGY}

This section of the paper explains the methodology adopted to achieve the objectives of the study. However, it starts with the theoretical literature, which links oil price and exchange rate with the manufacturing sector.

\subsection{Theoretical literature}

One of the prominent theories that investigated the relationship between manufacturing output, exchange rate, oil and economic growth is the Kaldor's theory of economic growth. Precisely, the first and second Kaldor's laws present the relation- 
ship between manufacturing output, other production resources and economic growth.

\subsection{The first Law of Kaldor's model of economic growth}

Kaldor (1957) made a linear model specification between economic growth and manufacturing output. That is

$$
g_{G D P}=a_{1}+b_{1} g_{m},
$$

where $g_{G D P}$ is the economic growth and $g_{m}$ is the manufacturing output. The importance of this is as follows: manufacturing is subject to increasing returns to scale, manufactured goods are the largest component of exports in an export led growth, and many services depend on manufactured goods. Since the revenues from export are denominated in foreign currency, hence, exchange rate plays significant role in influencing the value of the manufacturing sector output.

$$
g_{m}=a_{1}+b_{1} \operatorname{exr}_{m}
$$

where exr represents the current exchange rate, which affects the value of manufacturing output.

\subsection{The second Law of Kaldor's model of economic growth (Verdoorn's law)}

The law was tested in two ways firstly; a faster growth of output causes a faster growth of productivity.

That is

$$
p_{m}=a_{1}+b_{1} g_{m}
$$

where $p_{m}$ is manufacturing productivity and it is constructed from the difference between $g_{m}$ and employment growth $e_{m}$. However, the estimate of $b_{1}$ may be biased, that is $\left(p_{m}=g_{m}-e_{m}\right)$. In the relationship, $g_{m}$ is the manufacturing output and it is referred to as the Verdoorn's coefficient.

Secondly, manufacturing productivity is achieved based on availability of production resources. That is

$$
p_{m}=a_{2}+b_{2} \vartheta_{m}
$$

where the Verdoorn coefficient is $\left(1-b_{2}\right)$ and $\vartheta_{m}$ are resources needed for manufacturing production. According to Kaldor, the resources might be in the form of capital, which can be man-made or naturally endowed.

Combining equations 2,3 and 4 , making $g_{m}$ the subject of the formula, the resultant equation for manufacturing output is described in equation 5:

$$
g_{m}=a_{1}+b_{1} e_{m}+b_{2} \operatorname{exr}_{m}+\vartheta_{m}
$$

The implication is that apart from employment (labor), capital resources, which could be manmade or natural resources like oil and exchange rate, are important factors that determine manufacturing output.

\subsection{Model specification}

Following equation 5, the model for the study is derived and it describes the relationship between manufacturing output, oil, exchange rate, capital and other shift factors. The model is stated thus:

$$
\begin{aligned}
& \log g_{t}=\log A+\beta \log k_{t}+\infty \log \mathrm{Oil}_{t}+ \\
& +\partial \log \operatorname{exr}_{t}+\infty \log \theta_{t}+\varepsilon_{t},
\end{aligned}
$$

where $g_{t}$ is the manufacturing sector output growth rate at time $t, A$ is the intercept, $k$ is capital, $\beta$ is the elasticity of capital and it is equal to $\beta=1-\infty-\infty-\partial$, oil is oil price and $\theta_{t}$ is a control variable which comprises of other macroeconomic variables such as inflation rate, interest rate and money supply. $\varepsilon_{t}$ is the stochastic variable.

Oil price is the target variable in this study and it is viewed as oil price volatility and oil price change. As established in the background, the reason for this is to be able to appraise exchange rate responses to each of the oil price regimes, since it has been confirmed in the literature that they tend to have different implications for the economy of an oil dependent country like Nigeria (see Demachi, 2012). 


\subsection{Derivation of oil price volatility}

Leveraging on the arguments concerning the asymmetric effects of most of the commodity prices, the study adopts Exponential Generalized Auto-Regressive Conditional Heteroskedatcity EGARCH to generate oil price volatility. This enables to assess the possibility of the existence of asymmetric effect of oil price volatility.

The oil price volatility is developed via what is called EGARCH $[1,1]$ process. The oil price volatility is measured by estimating the following EGARCH model

$$
\operatorname{oilp}_{t}=\varphi+\operatorname{oilp}_{t-1}+\mu_{t}
$$

The AR[1] approach is followed. The following EGARCH model is estimated

$$
\ln \sigma^{2}=\omega+\ln \sigma_{t-1}^{2}+\alpha\left|\frac{\mu_{t-1}}{\sigma_{t-1}}\right|+\gamma\left|\frac{\mu_{t-1}}{\sigma_{t-1}}\right| .
$$

In equations 7 and 8 above, $\mu_{t}$ is a residual, and $\sigma$ denotes the conditional variance obtained from equation 8 . If $?<0$, it indicates the asymmetric nature of oil price volatility. This means that a negative oil price shock has a larger influence on the volatility than a positive oil price shock. In the SVAR analysis, the estimate of the conditional variance in equation 8 is used as crude oil price volatility.

\subsection{Derivation of oil price change via the Hamilton price index}

Literatures on SVAR have always been on positive shocks, and researchers are found of implying the reverse action as a result of negative shocks. Nevertheless, some authors have criticized this line of thinking that reaction to negative shocks might not necessarily produce a direct inverse reaction to positive shocks, hence, the need to device a means of examining the effects of negative shocks (Adeniyi, 2011). One of the ways of doing this is via the Hamilton index. To critically examine the responses of exchange rate and manufacturing output within the short run, the study derives the oil price change via the Hamilton index process. The usual assessment of oil price shock via positive deviation in oil price might not be suf- ficient in explaining appropriate policy direction, since the change in price of oil can be either a rise or a fall. Therefore, the Hamilton index process will enable us to explain the policy reaction relating to sharp jumps and drops in oil price, which have implications for an oil dependent economy like Nigeria.

Hamilton index was introduced in 1996 and it has been applied in studies like Ahmed and Wadud (2011), Demachi (2012) among others. The H1 extracts the net increase in oil price and the invH1 extracts the net decrease in oil price in a direct opposite manner. The process is described as follows:

$$
H 1_{t}=\left\{\begin{array}{l}
\left(\text { oilprice }_{t}-\max \text { oilprice }\right)> \\
>0,0 \text { for }\left(\begin{array}{l}
\text { oilprice }_{t}- \\
-\max \text { oilprice }
\end{array}\right) \leq 0
\end{array}\right\},
$$

and for the Inverse $H 1(\operatorname{InvH1})$ :

$$
\operatorname{InvH} 1_{t}=\left\{\begin{array}{l}
\left(\text { oilprice }_{t}-\text { min oilprice }\right)< \\
<0,0 \text { for }\left(\begin{array}{l}
\text { oilprice }_{t}- \\
- \text { min oilprice }
\end{array}\right) \geq o
\end{array}\right\},
$$

where max oilprice is the maximum oil price within the last one year and min oilprice is the minimum oil price within the last one year. The oil price used the natural log of the Brent crude oil price, which is similar to the Nigeria type of crude oil.

The two Hamilton price indices, both the $H 1$ and Inverse $H 1$, are used separately in the SVAR model to examine the reaction of the macroeconomic variable and the policy response within the short period.

\subsection{The SVAR model}

A six variable Structural Vector Auto Regression (SVAR) model is adopted following the study of Kilian (2009), Beckers and Beidas-Strom (2015). It contains five macroeconomic variables including the manufacturing sector growth rate. While oil price movements such as oil price volatility, $H 1$ and Inverse $H 1$ are the exogenous variables to the SVAR model. All the variables are in the log form and are described within the SVAR as fol- 
lows. Suppose the Nigerian economy is described in an SVAR model:

$$
A_{0} X_{t}=A_{1}(L) X_{t}+B \varepsilon_{t} .
$$

Here $L$ is a lag operator and

$$
X_{t}=[\text { oilprice, } \operatorname{msgr}, \text { inf }, M 2, \text { intr }, \text { exr }] \text {, }
$$

where oil price - $[H 1, \operatorname{InvH} 1$, volatility $]$ and $m s g r$ is the manufacturing sector growth rate, inf is a Consumer price index inflation rate, $M 2$ is the broad money supply, intr is the prime lending rate, and exr is the monthly average exchange rate of naira to USD. $A_{0}, A_{1}$ and $B$ are $6 \times 6$ coefficient vectors.

The reduced form of equation 11 is described as follows:

$$
X_{t}=\alpha+\sum_{t=1}^{p} \beta_{i} X_{t-i}+e_{t},
$$

where $p$ is the lag order and $e_{t}$ is the error vector for $6 \times 6$. For the identification, the authors follow Kilian (2009) where the model in equation 14 is considered:

$$
A e_{t}=\beta v_{t}
$$

The residual obtained from equation 13 is $e_{t}$ and the unobserved innovation is $v_{t}$. Based on Kim and Roubini (2000), Ahmed and Wadud (2011), zero restrictions are imposed on the $A$ and $\beta$, which are $6 \times 6$ vectors. This is shown in equation 15 :

From equation 15, one can have contemporaneous exogenous oil price shocks, which could be $H 1$, InvH 1 or volatility. None of the domestic variable affects the international commodity price, such as oil price, contemporaneously. Further behavioral restrictions imposed is that output and prices do not respond contemporaneously to domestic monetary policy variables and exchange rate. In this case, the manufacturing output is representing output and it is proxied by the output growth rate of the Nigerian manufacturing sector. Inflation is affected by the oil price as it influences the domestic money supply, interest rate and exchange rate of a country like Nigeria, where oil companies constitute major players in the movement of dollars in the domestic market. The exchange rate responds contemporaneously to the monetary policy variables as well as the inflation rate (see Kilian, 2009; Beckers \& Beidas-Strom, 2015).

\subsection{Data}

The International Financial Statistics (IFS) is the major source of data for the study. The Central Bank of Nigeria (CBN) database also serves as a guide. The data are extracted on a monthly basis from $200801 \mathrm{M}$ to $201709 \mathrm{M}$. This is the period when Nigerian economy experienced her second economic recession within the last two decades.

\section{RESULTS AND DISCUSSIONS}

The analysis begins with the examination of the time series properties of the data and assessing their suitability for the SVAR purpose. According to Narayan P. K. and Narayan S. (2007), variables to be included in the SVAR must be stationary and hence the Augmented Dickey-Fuller (ADF) test is conducted. The result is presented in Table 1.

The result of the ADF unit root test is an indication that all the variables are suitable for SVAR analysis since they are all stationary. While all oil price derivatives that is volatility, $H 1$ and $I n v H 1$,

$$
\left(\begin{array}{cccccc}
1 & 0 & 0 & 0 & 0 & 0 \\
0 & 1 & 0 & 0 & a_{25} & 0 \\
a_{31} & a_{32} & 1 & a_{34} & a_{35} & a_{36} \\
0 & a_{42} & 0 & 1 & a_{45} & 0 \\
0 & 0 & 0 & 0 & 1 & 0 \\
0 & 0 & a_{63} & a_{64} & a_{65} & 1
\end{array}\right)\left(\begin{array}{c}
\mu_{t}^{\text {oil }} \\
\mu_{t}^{m g r} \\
\mu_{t}^{i n f} \\
\mu_{t}^{M 2} \\
\mu_{t}^{L R} \\
\mu_{t}^{e x r}
\end{array}\right)=\left(\begin{array}{cccccc}
b_{11} & 0 & 0 & 0 & 0 & 0 \\
0 & b_{22} & 0 & 0 & 0 & 0 \\
0 & 0 & b_{33} & 0 & 0 & 0 \\
0 & 0 & 0 & b_{44} & 0 & 0 \\
0 & 0 & 0 & 0 & b_{55} & 0 \\
0 & 0 & 0 & 0 & 0 & b_{66}
\end{array}\right)\left(\begin{array}{c}
e_{t}^{\text {oil }} \\
e_{t}^{m g r} \\
e_{t}^{i n f} \\
e_{t}^{M 2} \\
e_{t}^{L R} \\
e_{t}^{e x r}
\end{array}\right) .
$$


Table 1. ADF unit root test

\begin{tabular}{|c|c|c|}
\hline Variable & ADF statistics & Order of integration \\
\hline Oil price & -6.876309 & $\mathrm{I}(1)$ \\
\hline Oil price volatility & -7.467447 & $\mathrm{I}(0)$ \\
\hline $\mathrm{H} 1$ & -3.503911 & $I(0)$ \\
\hline InvH1 & -2.897084 & $\mathrm{I}(0)$ \\
\hline Exchange rate EXR & -8.189230 & $\mathrm{I}(1)$ \\
\hline Inflation rate INF & -5.983571 & $I(1)$ \\
\hline Money supply M2 & -11.29782 & $\mathrm{I}(1)$ \\
\hline Manufacturing sector growth rate & -11.95658 & $I(1)$ \\
\hline Interest rate (lending rate) & -8.216161 & $\mathrm{I}(1)$ \\
\hline
\end{tabular}

do not possess unit root, hence they are all stationary at levels, other macroeconomic variables are all integration of order one that is $\mathrm{I}(1)$.

\subsection{Oil price volatility}

The estimated EGARCH equation for the oil price is presented in equation 16. Again, the EGARCH is applied here in order to verify if oil price volatility is asymmetric or not. The estimated equation for the EGARCH is presented as follows:

$$
\begin{aligned}
& \ln \sigma^{2}=-0.936242^{* *}+0.637045^{* *} \ln \sigma_{t-1}^{2}- \\
& -0.168374^{* *}\left|\frac{\mu_{t-1}}{\sigma_{t-1}}\right|+0.915053^{* *}\left|\frac{\mu_{t-1}}{\sigma_{t-1}}\right| .
\end{aligned}
$$

$$
\text { (0.248357) (0.168936) (0.082580) (0.053894) }
$$

Equation 16 is the estimated EGARCH model presented in equation 8 . The result shows that oil price does not have asymmetric effect in Nigeria but rather a significant symmetric effect during the period under review. This is because the coefficient is greater than zero and it is statistically significant. This indicates that a positive oil price shock instead of a negative oil price shock will have more pronounced effect on volatility. It implies that between January 2009 and September 2017, oil price volatility does not have asymmetric effect. The result is similar to Demachi (2012).

\subsection{Descriptive statistics}

The three derivatives from oil price, which measure oil price volatility and oil price change, are presented in Figures 1-3 to examine their individual pattern of movements between January 2008 and September 2017.

Figures 1 to 3 compare and describe oil price movement in terms of its volatility, $H 1$ and InvH1 within January 2008 and September 2017. The graph of oil price volatility clearly shows that oil price has been dynamic during the period under review with the peak recorded in 2014 and the least recorded in 2008. By comparing the three, it is obvious that their effects on macroeconomic variables will definitely be different as they show different trends, therefore, the inclusion of each of them as exogenous variable in the SVAR is, however, justified.

OILPVOL

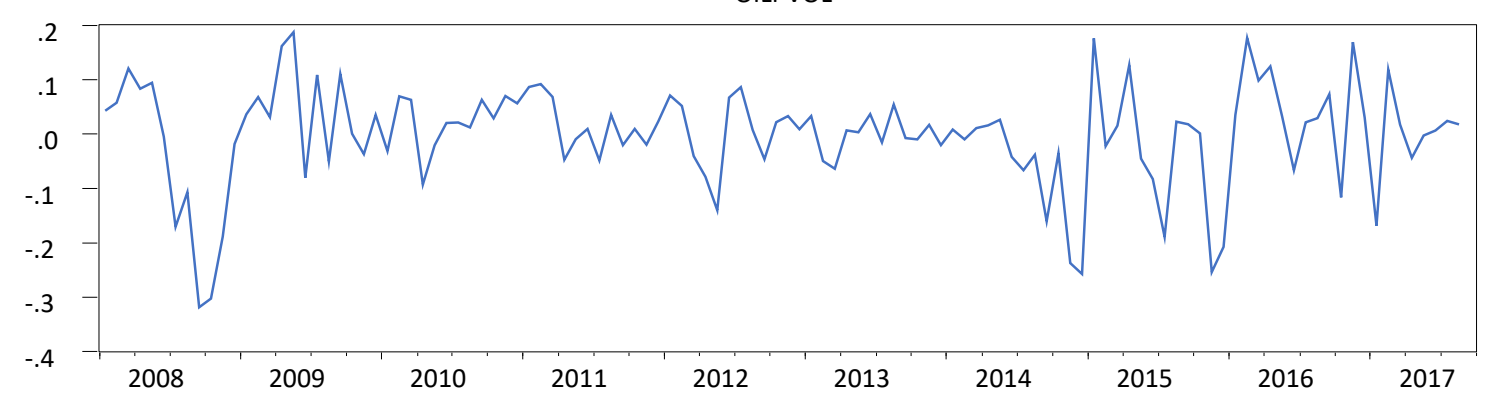

Figure 1. Oil price volatility (from 2008M01 to 2017M09) 
H1

Source: Author's computation (2017).

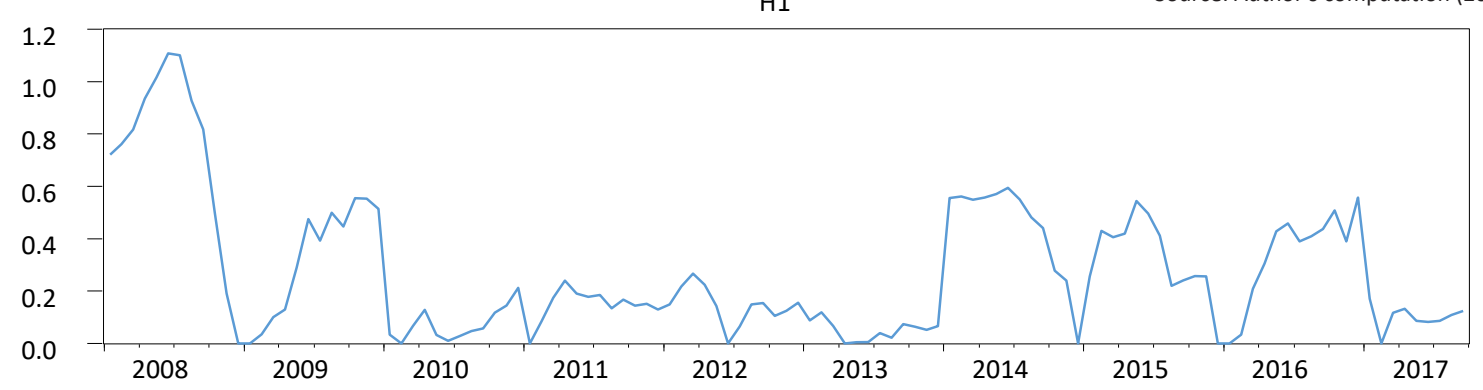

Figure 2. Hamilton index (2008M01 to 2017M09) $H 1$

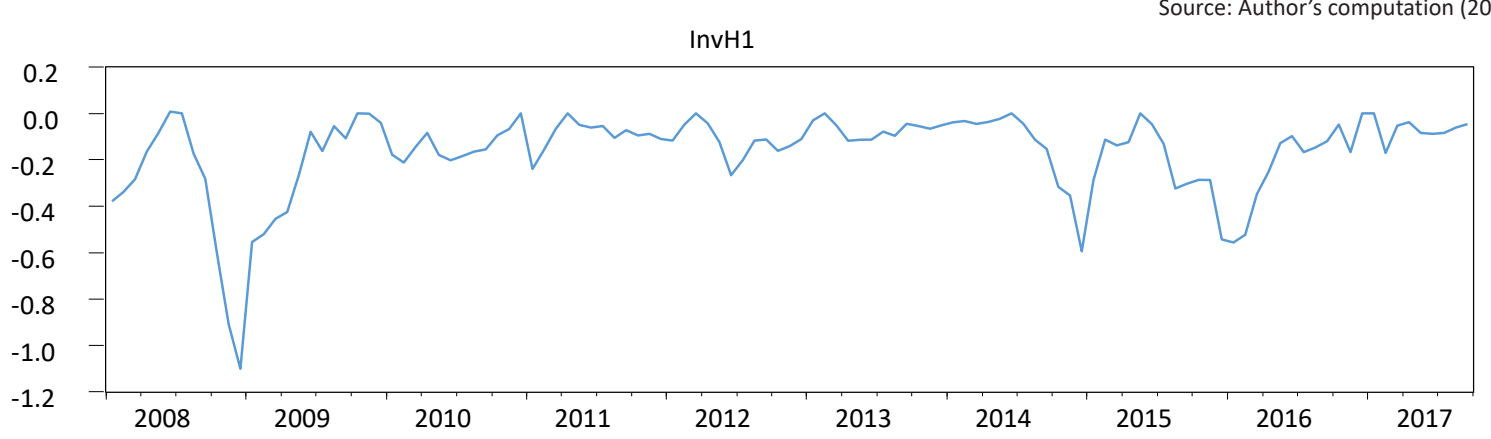

Figure 3. Inverse Hamilton index (from 2008M01 to 2017M09) InvH1

\subsection{Impulse response functions}

The impulse response functions describe the reactions of variables to $1 \%$ standard deviation in another variable. We begin with the reactions of the macroeconomic variables to oil price volatility.
Figure 4 describes the responses of the macroeconomic variables to oil price volatility. From the graphs, it can be seen that oil price volatility has significant impact on manufacturing output growth, especially in the middle of the period. Money supply also shows significant response

Source: Author's computation (2017).
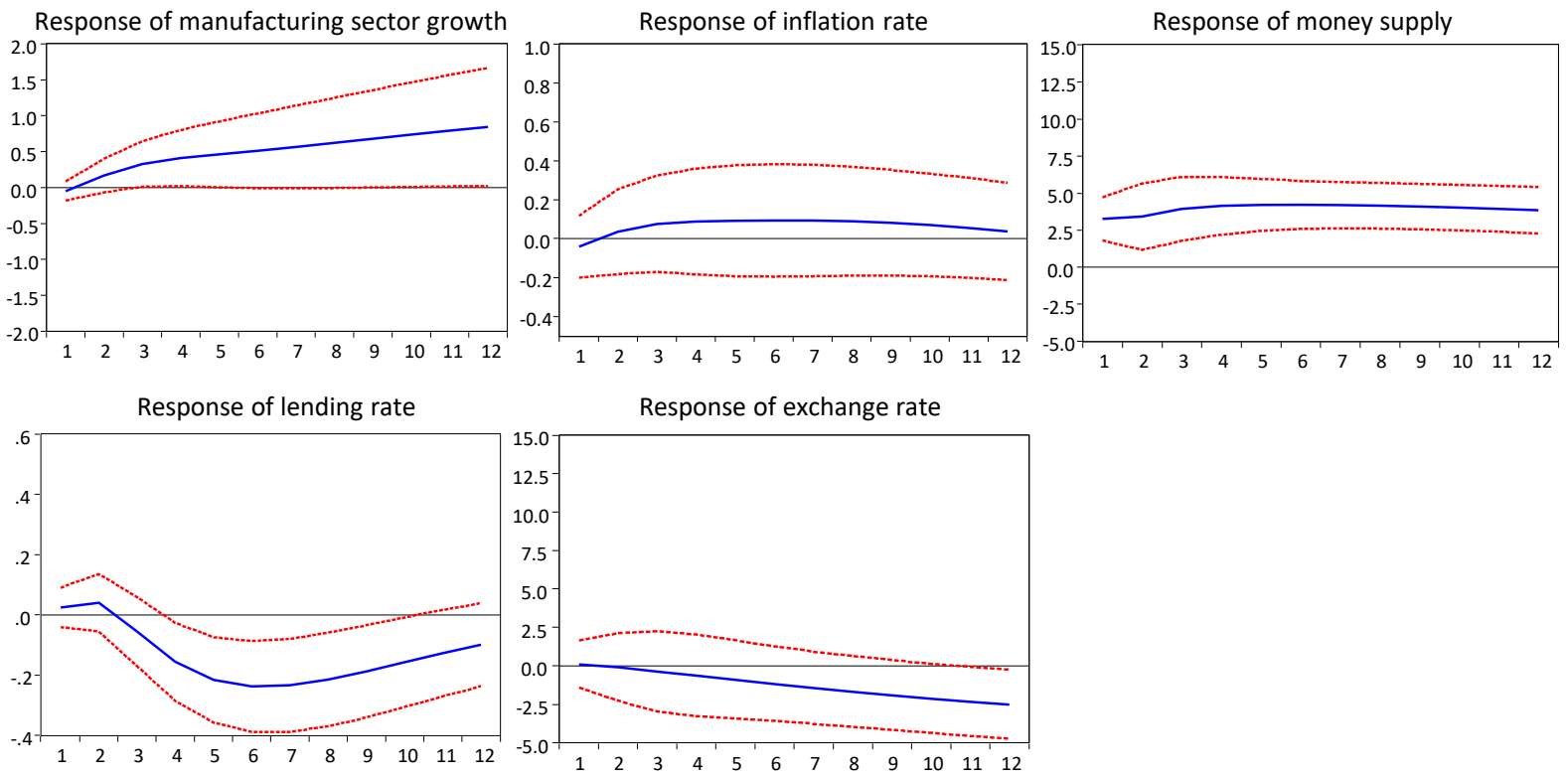

Figure 4. Response to oil price volatility 

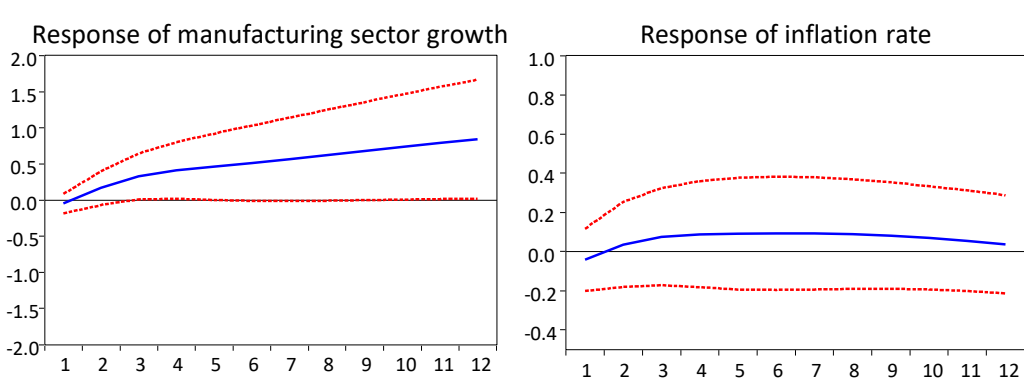

Source: Author's computation (2017).
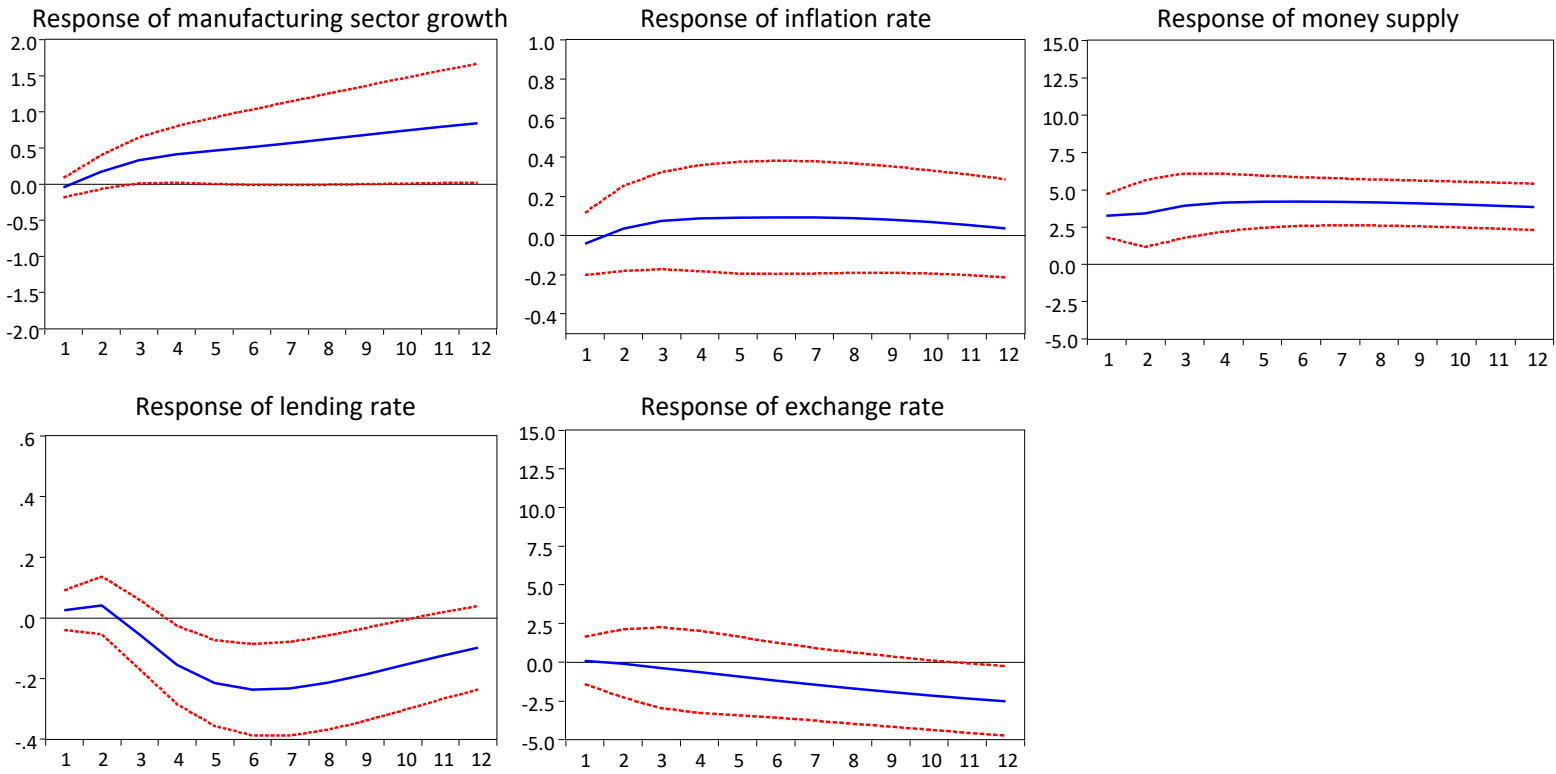

Figure 5. Response to $H 1$

to the shock from oil price volatility. This is because the dynamics in oil price affect the supply of money domestically, since giant oil companies in Nigeria are important players in the supply of dollars into the economy.

The responses of the macroeconomic variables to a sharp jump in oil price are explained in Figure 5. It is obvious from the graph that the reactions of the variables are almost like that of oil price volatility. Nevertheless, it appears that oil price sharp jump has more pronounced effect on the manufacturing sector growth than oil price volatility. The sharp increase in oil price just like oil price volatility causes money supply to rise significantly, but unlike oil price volatility, the sharp increase in oil price causes the interest rate to fall significantly. The reason for this might not be unconnected to the fact that money supply rises because of increase in supply of dollars to the domestic economy. The effect of this is also seen on the exchange rate, which appreciates though, it is not significant
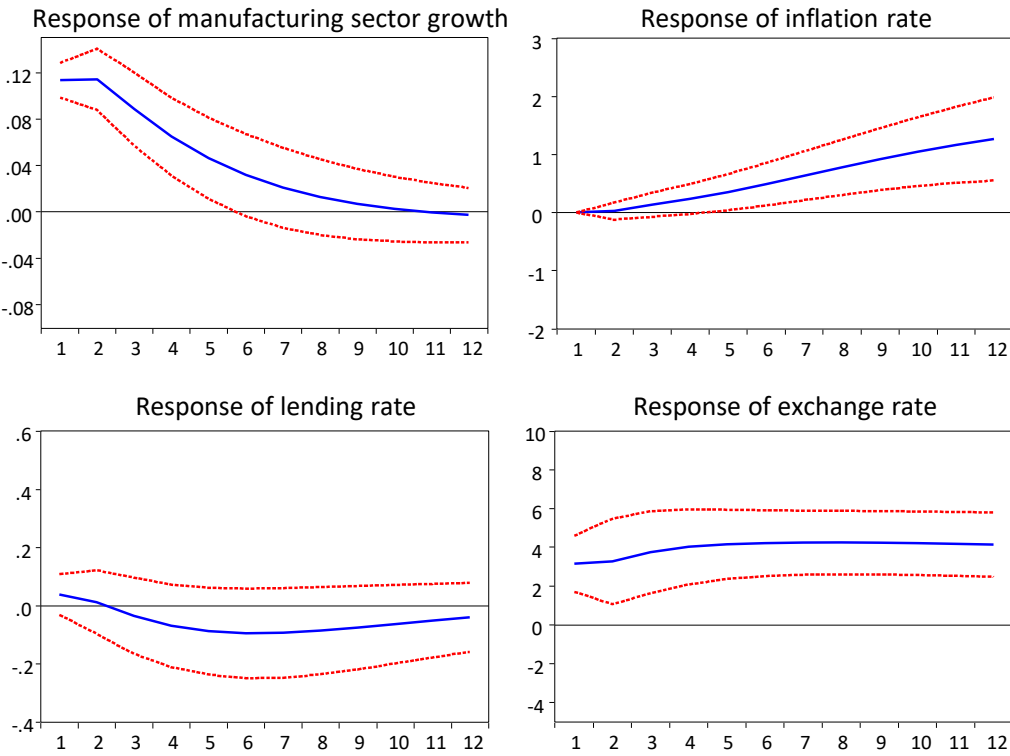

Figure 6. Response to $\operatorname{InvH1}$
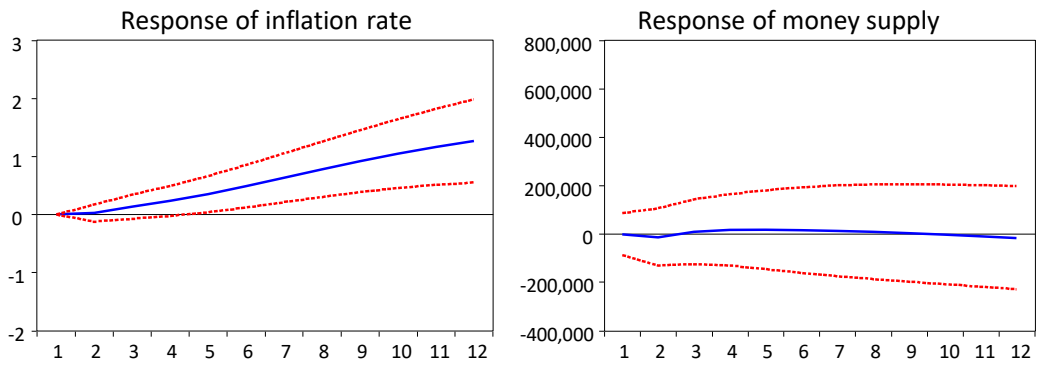

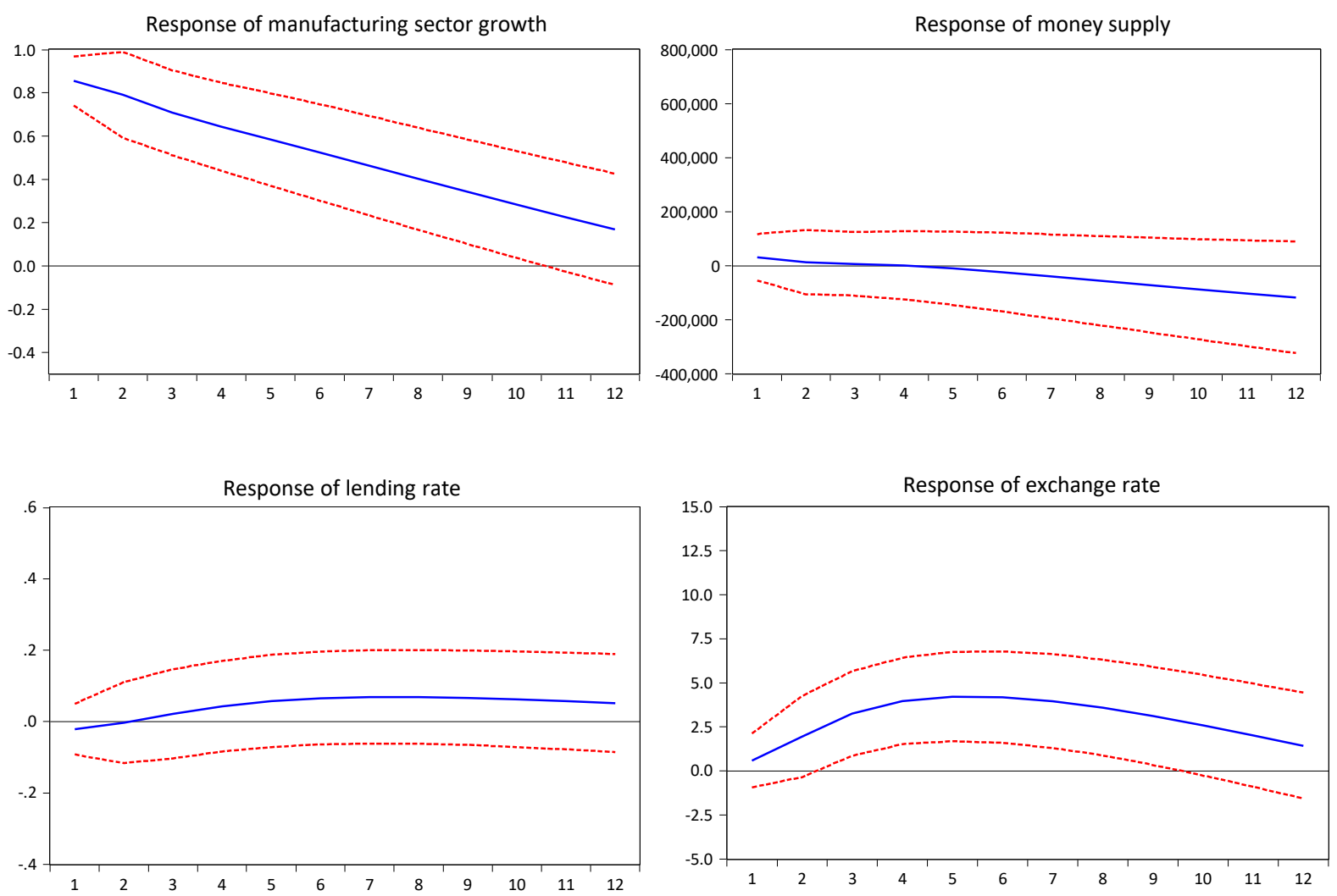

Figure 7. Response to inflation rate shock

initially, but towards the end of the period, the exchange rate appreciates significantly. The cumulative effect of all these is seen on the rise in the manufacturing sector growth even as the sharp increase in the oil price fails to have significant impact on inflation rate.

The reactions of the manufacturing sector growth and other macroeconomic variables to a sharp decline in oil prices are explained in Figure 6. The manufacturing sector growth shows a sharp and significant decline in reaction to the sharp drop in oil price. Inflation rate also rises but this time significantly. It should be noted that in the previous figure under the sharp rise in oil price, inflation also rises, but not significantly. These phenomena have further justified the usage of Hamilton index to study the negative shock effect. The sharp drop in oil price fails to produce direct opposing reaction from the inflation rate. The money supply and the interest rate fail to respond significantly to the sharp drop in oil price which is another scenario, where the reactions to negative shock fails to produce direct opposite reactions to positive shock.
Lastly, the exchange rate depreciates significantly. This further explains why there is a sharp fall in the manufacturing sector growth even as inflation rises as well.

Inflation rate has been shown as a powerful shock in the impulse response function. Notwithstanding, money supply and lending rate do not respond significantly to the shock. However, manufacturing sector growth rate shows a sharp decline in reaction to inflation shock. In the same vein, exchange rate is another variable that shows significant response to the inflation rate shock. It causes the exchange rate to depreciate at least for the most part of the periods.

Figure 8 shows that only lending rate and exchange rate exhibit significant reactions to money supply shock. It causes the lending rate to fall, while it makes the naira to depreciate. However, it fails to produce significant reactions from both the inflation rate and manufacturing sector growth rate.

Money supply and manufacturing sector growth are the two variables that show significant re- 


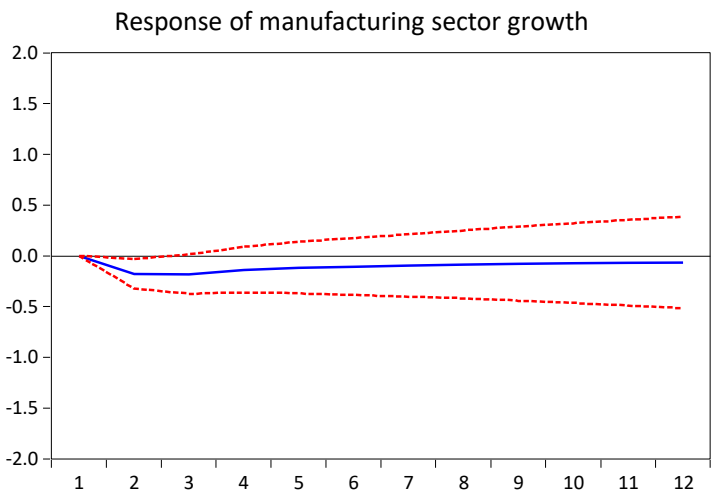

Response of inflation rate
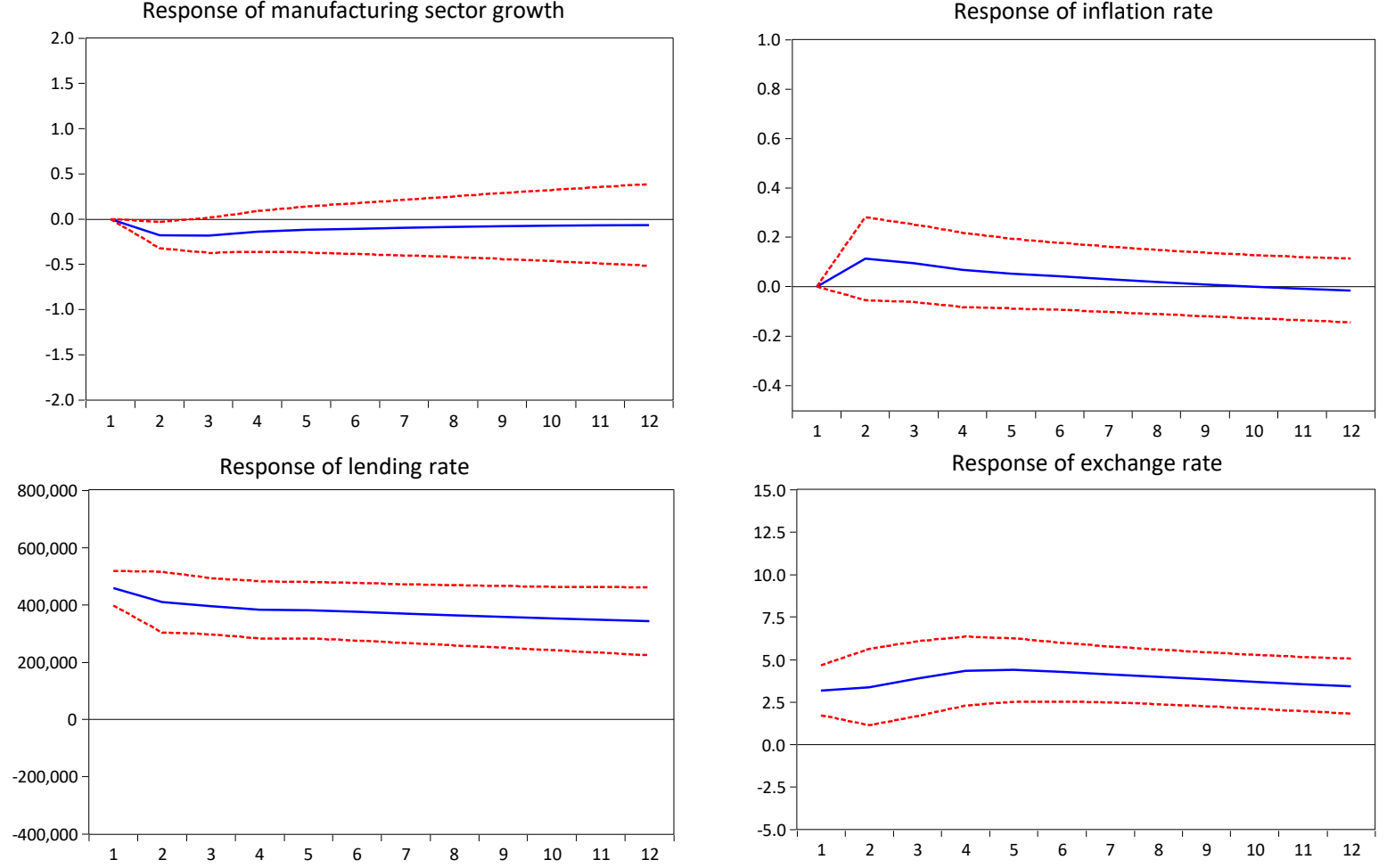

Figure 8. Response to money supply shock
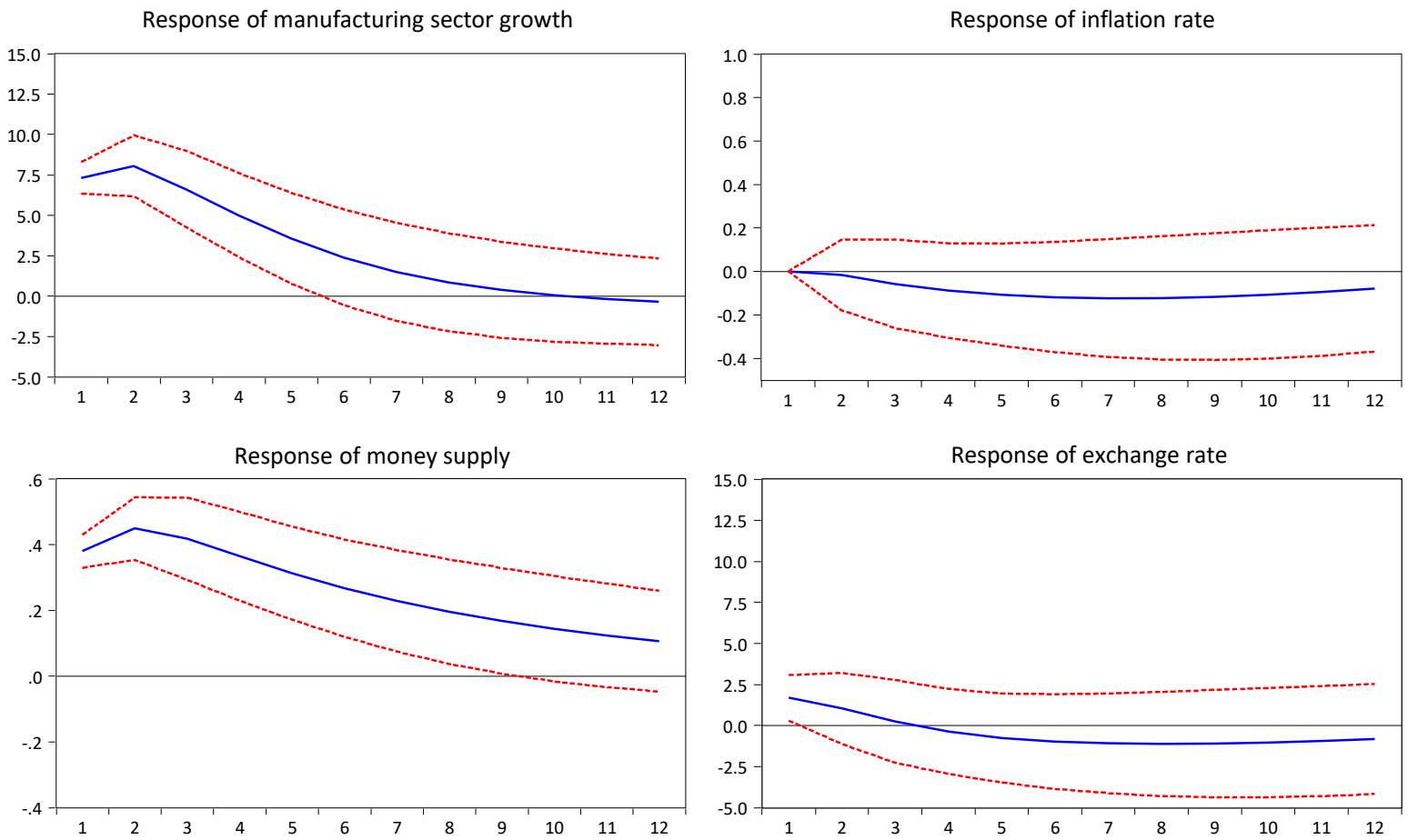

Figure 9. Response to lending (interest rate) shock 

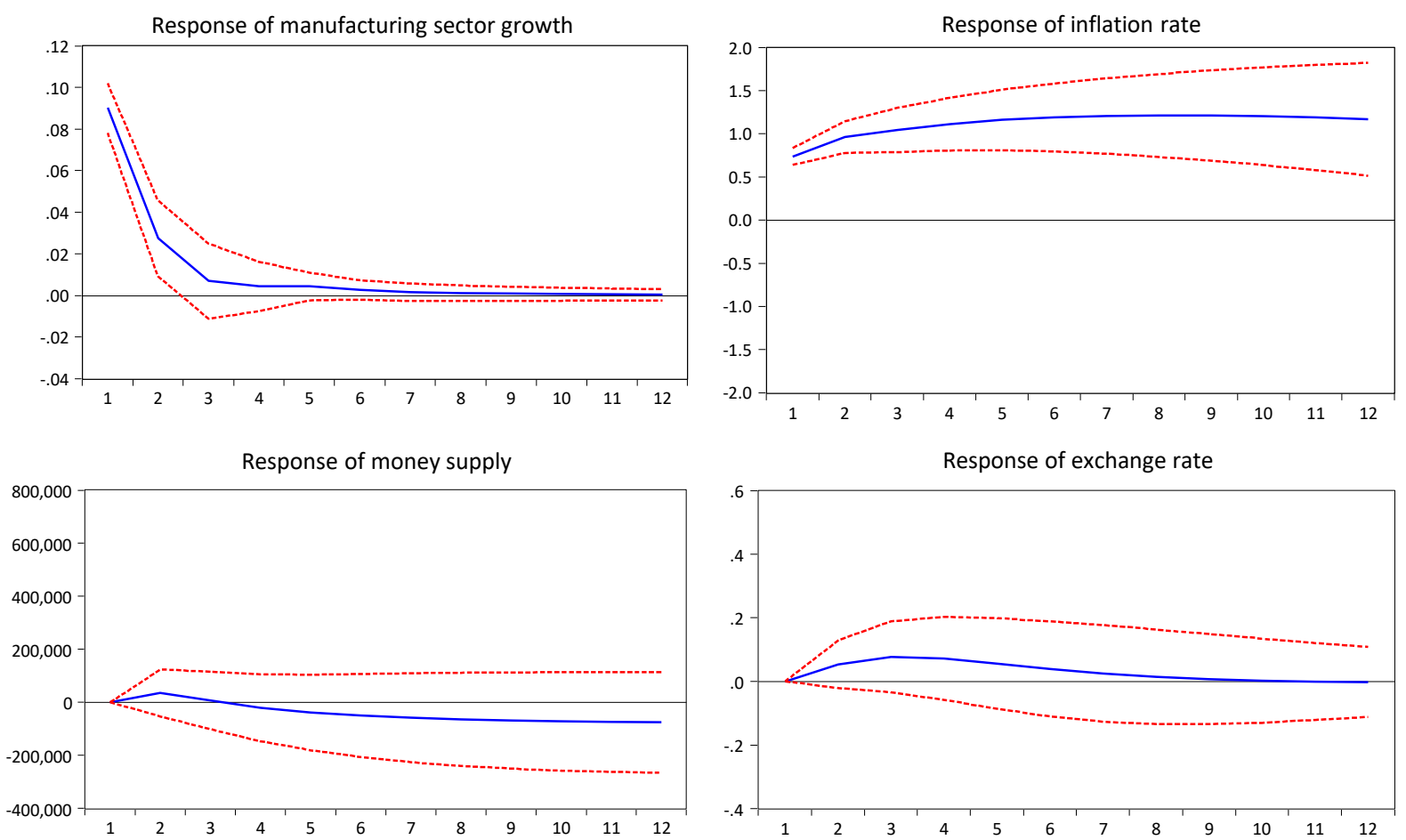

Figure 10. Response to exchange rate shock

sponses to lending rate shocks. Money supply declines significantly because of the interest rate shock, while the manufacturing sector growth rate also falls significantly. However, both inflation rate and exchange rate do not react significantly to the lending rate shock.

Unlike the insignificant reactions of inflation rate to the monetary policy shocks, inflation rate reacts significantly to the shock from the exchange rate. It implies that a sharp fall in the value of the naira leads to sharp rise in the domestic CPI inflation rate. However, the exchange rate shock also produces a sharp fall in the manufacturing sector growth, thus implying that depreciation of naira might not promote the growth of the manufacturing sector in Nigeria.

\subsection{Variance decomposition}

The variance decomposition explains the relative contributions of various shocks to the behavior of a particular variable.

From Tables 2 and 3, the dominance of oil price derivatives in the behavior of the manufacturing sector growth is obvious. In Table 2, oil price volatility contributes the highest shocks to the behavior of the manufacturing sector growth. The same situation is also noticed in Table 3. However, in Table 4, apart from the own shock, fall in the oil price and exchange rate both contribute the highest shocks to the behaviors of the manufacturing sector growth rate. Again, in all the tables, inflation rate is another macroeconomic variable that

Table 2. Variance decomposition for the manufacturing sector growth rate

Source: Author's computation (2017).

\begin{tabular}{|c|c|c|c|c|c|c|}
\hline Period & OILPVOL & MVAGR & INF & M2 & LR & EXR \\
\hline 3 & 79.31168 & 18.28746 & 0.085936 & 0.000859 & 2.310776 & 0.003284 \\
\hline 6 & 88.88502 & 7.067461 & 0.407103 & 0.004071 & 3.632068 & 0.004273 \\
\hline 9 & 89.00968 & 5.120959 & 0.861990 & 0.008620 & 4.991773 & 0.006979 \\
\hline 12 & 88.08942 & 4.213648 & 1.356660 & 0.013567 & 6.316349 & 0.010353 \\
\hline
\end{tabular}


Table 3. Variance decomposition for the manufacturing sector growth rate

Source: Author's computation (2017).

\begin{tabular}{c|c|c:c:c:c:c}
\hline Period & H1 & MVAGR & INF & M2 & LR & EXR \\
\hline 3 & 78.58147 & 19.04244 & 0.156311 & 0.001563 & 2.212450 & 0.005760 \\
\hdashline & 83.06649 & 13.82439 & 0.317823 & 0.003178 & 2.781050 & 0.007063 \\
\hdashline & 87.02643 & 6.389646 & 1.175310 & 0.011753 & 5.386674 & 0.010183 \\
\hdashline & 87.59161 & 4.427401 & 1.523100 & 0.015231 & 6.431275 & 0.011381 \\
\hline 12 & & &
\end{tabular}

Table 4. Variance decomposition for the manufacturing sector growth rate

Source: Author's computation (2017).

\begin{tabular}{c|c|c|c|c:c:c}
\hline Period & InvH1 & MVAGR & INF & M2 & LR & EXR \\
\hline 3 & 40.26586 & 53.39554 & 0.396123 & 0.003962 & 0.006876 \\
\hline 6 & 20.89689 & 58.79647 & 3.474166 & 0.034743 & 0.022345 & 16.77538 \\
\hline 9 & 11.69910 & 50.58150 & 9.405429 & 0.094056 & 0.063681 & 28.15623 \\
\hline 12 & 11.11252 & 46.24040 & 11.26850 & 0.112687 & 0.079370 & 31.18652 \\
\hline
\end{tabular}

contributes significant shock to the behavior of the manufacturing sector growth rate.

\section{DISCUSSIONS}

Some new lines of discussion have been thrown up by the findings in this research work. Firstly, the effects of oil price volatility and oil price change on the manufacturing sector growth rate and other macroeconomic variables are multifaceted. Oil price volatility and a sharp increase in the oil price $\mathrm{H} 1$ generate almost similar responses from the variables. They both cause manufacturing sector growth to rise, but while sharp increase in oil price causes money supply to rise significantly, oil price volatility does not have significant impact on money supply. Their impacts on inflation rate are also not significant though, sharp increase in oil price causes the exchange rate to appreciate but not significantly as well. The implication of this result is that increase in oil price might not have much inflationary tendency. This is similar to the result of Demachi (2012) where a sharp jump in oil price led to an increase in money supply. The reason for this is that foreign oil companies, which dominate the Nigerian oil industry, realize more dollars. Naira also appreciates because of this but not significantly.
The reaction of the variables to a sharp fall in oil price is that InvH1 appears to be different in some aspects. For instance, unlike oil price volatility and H1, manufacturing sector growth rate reacts negatively to a sharp decline in oil price. In addition, inflation rate rises significantly, while naira depreciates significantly. The implication of these chains of reactions is that fall in oil price appears to have much more negative impacts on the macroeconomic variables than both oil price volatility and increase in oil price. Explicitly, the trends of reactions are as follows: the sharp decline in oil price causes the exchange rate to rise, that is naira depreciates. This leads to increase in the prices of imports and since many of the local manufacturers depend on the foreign countries for supply of both raw materials and capital goods for domestic production, their outputs decline and this leads to rise in inflation. It should be noted that the monetary policy variables fail to react significantly to the fall in the oil price.

Furthermore, the results from the study have also shown that monetary policy shocks cause the manufacturing sector growth to fall significantly. This supports the results of Olomola (2007) where high interest rate was described as the major challenge to the Nigerian manufacturers. However, inflation rate has been shown from the result to be highly linked to the fall in oil price, which depreciates the value of naira significantly. 


\section{CONCLUSION AND RECOMMENDATIONS}

Some important conclusions can be drawn from the findings of this study. Firstly, the study has shown that it might be wrong for previous studies using SVAR to imply that a negative oil price shock will always produce reactions that are direct opposite to the positive oil price shocks. The Hamilton index adopted in the study has shown that both sharp jump and drop in oil price will make the inflation rate rise. However, while the rise is significant for sharp drop in oil price, it is not significant for sharp rise in oil price.

The manufacturing sector has been shown from the study to be more reactive to drop in oil price than rise in oil price. This is evident from the significant effects it has on both inflation rate and exchange rate. The sharp drop in oil price causes the exchange rate to rise, that is naira depreciates. This leads to increase in the prices of import goods such as raw materials and capital goods, which constitute serious cost implications for the manufacturing industry in Nigeria. The rising cost of import goods triggers domestic inflation and hence it affects the outputs of the Nigerian manufacturing sector. The implication of this is that domestic manufacturers in Nigeria are highly affected by increase in cost of production. In view of this, the action of the CBN to devalue the naira in order to improve investment at the second quarter of 2016 prior to the economic recession might not be justified. This is because despite this action, the manufacturing PMI fell further by 5\% in the third quarter of 2016 and the overall economic growth became negative for the second successive quarter, which brought the economy into recession.

Again, the study has shown that the nature of inflation in Nigeria might not be a monetary phenomenon but a structural phenomenon. Findings in the study have shown that inflation in Nigeria reacts more to prices and output imbalances instead of money supply. Again, the action of the CBN to be attacking the rising inflation in Nigeria from the monetary angle might not be empirically justified. The CBN has been following a contractionary monetary policy since December 2015 when the monetary policy rate rose from $12 \%$ to $14 \%$ and the lending rate rose by $2 \%$ as well. This action appears to have compounded the woes of the Nigerian manufacturing sector even as the cost of capital became too expensive for the reach of average manufacturers. This led to further decline in the manufacturing value added by $3.5 \%$ in the third quarter of 2016.

Generally, utilization of oil proceeds during the periods of oil boom to promote the manufacturing sector growth will go a long way to improve the manufacturing sector of the Nigerian economy. It is also recommended that provision of avenues, through which manufacturers can have easier access to funds, should be encouraged. In addition, efforts should be made to address the rising cost of production by stemming the tide of growing inflation rate and finally, falling exchange rate, which has led to increase in the cost of imported raw materials, need to be tackled.

\section{REFERENCES}

1. Adeniyi, O. A. (2011). Oil Price Shocks and Economic Growth in Nigeria: Are Thresholds Important? Journal of Economics and Business Studies, Redeemers University, 4(7), 43-78. https://doi.org/10.1111/ j.1753-0237.2011.00192.x

2. Ahmed, H. J. A., \& Wadud, I. K. (2011). Role of oil price shock on macroeconomic activities: An SVAR approach to the Malaysian economy and monetary responses.
Energy Policy, 39(5), 8062-8069. https://doi.org/10.1016/j.enpol.2011.09.067

3. Amuzegar, A. (2001). OPEC as Omen. Journal of Foreign Affairs, 77(6), 95-129. Retrieved from https://www.researchgate.net/ publication/272544272_OPEC_as_ Omen

4. Apere, O., \& Ijomah, A. M. (2013). Macroeconomic Impact of Oil Price
Levels and Volatility in Nigeria. International Journal of Academic Research in Economics and Management Sciences, 2(4), 15-25. Retrieved from http://citeseerx.ist. psu.edu/viewdoc/download?doi $=10.1 \cdot 1 \cdot 679.2738 \& \mathrm{rep}=\mathrm{rep} 1 \&$ typ $\mathrm{e}=\mathrm{pdf}$

5. Bernanke, B. (1986). Alternative explanation of the money-income correlation (NBER Working Paper Series, No. 1842, 1-62). 
6. Beckers, B., \& Beidas-Strom, S. (2015). Forecasting the Nominal Brent Oil Price with VARs - One Model Fits All? (IMF Working Paper, Research Department).

7. Becklemans, L. (2005). Credit and monetary policy: An Australian SVAR (Reserve Bank of Australia Research Discussion Paper Series No. 1, 2-9)

8. Berument, H., \& Ceylan, N. (2005). Effects of exchange rate risk on economic performance in Turkey. Applied Economics, 36(23), 2429-2441.

9. CBN (2017). Statistical Bulletin, Vol 21, Central Bank of Nigeria, Abuja, December.

10. Demachi, K. (2012). Effects of crude oil voalitity and change on the Nigerian economy (MPRA Paper No. 41413).

11. Elbourne, A. (2007). The UK housing market and the monetary policy transmission mechanism: An SVAR approach. Journal of Housing Economics, 17(8) 65-87.

12. Engle, R. F. (1995). ARCH Selected Readings, Advanced Texts in Econometrics. Oxford: Oxford University Press.

13. Ferderer, J. P. (1996). Oil Price Volatility and the Macroeconomy. Journal of Macroeconomics, 18(1), 1-26.

14. Gachara, A. (2015). Channels through which oil price shocks affect economic activity in Kenya. International Journal of Energy Economics and Policy, 3(2), 143-152.

15. Hamilton, J. D. (1983). Oil and the Macroeconomy since World War II. Journal of Political Economy, 91(2), 228-248.

16. Hamilton, J. D. (1996). This is what happened to the oil pricemacroeconomy relationship. Journal of Monetary Economics, 38, 215-220.

17. Hamilton, J. D. (2003). What is an oil shock? Journal of Econometrics, 113, 363-398. https://doi. org/10.1016/S0304-4076(02)00207-5

18. Hamilton, J. D. (2008). Understanding Crude Oil Price (NBER Working Paper, 14492).

19. Hooker, M. A. (2001). What Happened to the Oil Price
Macroeconomy Relationship. Journal of Monetary Economics, 38, 195-213.

20. IMF (2016). International Monetary Fund economic report: Africa focus. Special Issue, No. 49, 1-29.

21. Iwayemi, A., \& Fowowe, B. (2011) Impact of oil price shocks on selected macro- economic variables in Nigeria. Energy Policy, 39, 603-612. Retrieved from https:// ideas.repec.org/a/eee/enepol/v39y2011i2p603-612.html

22. Joseph, B., \& Festus, A. (2013). Oil price dynamics, fiscal stance and macroeconomic effects in Nigeria. Interdisciplinary Journal of Contemporary Research in Business, 4(1), 149-155.

23. Kaldor, J. F. (1957). Model of economic growth and manufacturing output. The Energy Journal, 4, 151-162.

24. Kalamova, T. (2007). The Equilibrium Real Exchange Rate in a Commodity Exporting Country: Algeria's Experience (IMF Working Paper 135).

25. Kilian, R. E. (2009). Macroeconomic priorities. American Economic Review, 931, 1-14.

26. Kim, S., \& Roubini, N. (2000). Exchange rate anomalies in the industrial countries: A solution with structural VAR Approach. Journal of Monetary Economics, 45(3), 561-586. Retrieved from https://ideas.repec.org/a/eee/moneco/v45y2000i3p561-586.html

27. Kutu, A. A., \& Ngalawa, H. (2016) Monetary Policy Shocks and Industrial Sector Performance in South Africa. Journal of Economics and Behavioral Studies, 8(3), 26-40.

28. Majid, A. (2006). The contribution of oil sector to Arab economic development (OFID Pamphlet Series, No. 23, 45-90).

29. Musa, K. (2015). Diagnosing Dutch-Disease: Does Russia have the Symptoms? (IMF Working Paper No. 102, 14-32).

30. Narayan, P. K., \& Narayan, S. (2007) Modelling oil price volatility. Energy Policy, 35(12), 6549-6553.
31. NBS (2016). National Bureau of Statistics Annual Abstract, No. 21, 3-32.

32. Nikbakht, R. (2010). Exchange rate volatility and non-traditional exports performance: Zambia, 1995-2009.

33. Ojo, Y., \& Alege, P. (2012). A business cycle model for Nigeria. Paper presentation at the African Econometric Society Conference 2009 Abuja, Nigeria.

34. Olomola, P. (2006). Oil wealth and economic growth in African oil exporting countries. AERC research paper, No. 170, 23-45.

35. Oomes, N., \& Kalcheva, K. (2007). Diagnosing Dutch Disease: Does Russia Have the Symptoms? (BOFIT Discussion Paper, 7).

36. Omolade, A., \& Ngalawa, H. (2014). Oil revenue and manufacturing sector growth in Africa's oilexporting countries. Journal of Economic and Financial Sciences, 7(3), 925-944.

37. Sims, C. A. (1986). Are forecasting models usable for policy analysis? Quarterly Review of Federal Reserve Bank of Minneapolis, 10(1), 2-16.

38. Sousa, R., \& Zaghini, T. R. (2007). Monetary policy effectiveness under the CEMAC area: Empirical evaluation. International Journal of Advances in Management and Economics, 2(4), 55-64.

39. Spatafora, N., \& Stavrev, E. (2003). The Equilibrium Real Exchange Rate in a Commodity Exporting Country: The Case of Russia (IMF Working Paper 93).

40. Stauffer, M. E. (1984). Xtivreg2: Stata module to perform extended IV/2SLS, GMM and AC/HAC, LIML and $k$-class regression for panel data models. Retrieved from http://ideas. repec.org/c/boc/bocode/s456501. html (accessed on January 6, 2018).

41. Vahid K., \& Jabber, P. (1997). Political and economic reform in the Muslim World. Globicom, New York.

42. Vonnak, B. (2005). Estimating the effects of Hungarian monetary policy within a structural VAR framework (Magyar Nemzeti Bank Working Paper Series, No. 38, 1-37). 